\title{
1. Immigration in Spain: migratory routes, cooperation with third countries and human rights in return procedures
}

\author{
Inmaculada González García ${ }^{1}$
}

\section{INTRODUCTION}

According to data published by the Office of the United Nations High Commissioner for Refugees (UNHCR), ${ }^{2}$ a total of 17,430 immigrants and refugees arrived in Spain between 1 January and 30 September 2017, almost double the number of those recorded in the previous year for the same period $(9,148){ }^{3}$ Arrivals by sea accounted for most of this increase in immigration (12,420 compared with 5,446 in 2016), but arrivals by land to the autonomous cities of Ceuta $(1,922)$ and Melilla $(3,506)$ have also escalated (a total of 5,010 compared with 3,702 in 2016). These cities have also witnessed a rise in arrivals by sea, to a greater extent in Ceuta than in Melilla, including arrivals

1 This research was carried out in the framework of the Research Project "España, Seguridad y Fronteras Exteriores Europeas en el Área del Estrecho" [Spain, Security and the EU's External Borders in the Area of the Strait] (DER2015-68174-R (2016-2018)), financed by the Spanish Ministry of Economy and Competitiveness and the European Regional Development Fund (Principal Investigators: Dr Alejandro del Valle Gálvez and Dr Inmaculada González García), and also in the framework of the Centre of Excellence Jean Monnet 'Migration and Human Rights in Europe's External Borders', with the support of the Erasmus+ Programme of the European Union. In the analysis of the immigrant boat crisis (cayucos crisis), the author was assisted by the Professors Miguel A. Acosta Sánchez and Alejandro del Valle Gálvez, members of these Research Projects.

2 http://data2.unhcr.org/en/situations/mediterranean/location/5226 accessed 5 April 2019.

3 The data for 2016 are available in Spanish Commission for Refugee Aid (Spanish initials: CEAR), 'Movimientos migratorios en España y Europa' (Report 2016) https:// www.cear.es/wp-content/uploads/2017/02/Informe-rutas-migratorias.pdf accessed 5 April 2019. 
to the Spanish islands and islets in North Africa. ${ }^{4}$ The only time the number of immigrants arriving in Spain by land surpassed the number arriving by sea was in the period 2013 to 2015 , mainly due to increased immigration from Syria. ${ }^{5}$

Maritime routes thus comprise the main gateway for irregular immigration to Spain, principally to the Andalusian coast (with 11,119 immigrants between January and September 2017), followed by the Mediterranean coast (746 in the same period) and the Canary Islands (137 arrivals). This predominance has been heightened by the Spanish Government's decision to reinforce the border fences surrounding Ceuta and Melilla, following the first mass assaults on the fences in 2005, ${ }^{6}$ and adopt a new 'procedure' of rejection at the border in these cities, which entered into force on 1 April 2015 . $^{7}$

Thus, in the first seven months of 2017, the number of immigrants reaching the Spanish coast tripled. This increase in immigration has coincided with the application of stricter measures against human trafficking by sea between

4 The influx of boats to the Spanish islands intensified in 2012 with the arrival of 250 immigrants on the Isla de Alborán between January and August, while others arrived in late August on the uninhabited Isla de Tierra, which together with the Isla de Mar, both located a few metres from the Moroccan coast, forms part of the Peñón de Alhucemas archipelago. The Peñón de Vélez de La Gomera is the only Spanish island connected to Morocco by an isthmus, and is also the only Spanish island to have remained unaffected by these new waves of immigrants. See 'La inmigración marca nuevas rutas a los islotes españoles. Tanto la isla de Perejil como Chafarinas han sido destinos de algunos de los subsaharianos que salen de Marruecos' (21 May 2012) El Pueblo de Ceuta; 'A Melilla vía Islas Chafarinas' (18 May 2012) El Mundo; and 'Peñones e islotes: la nueva entrada de los "sin papeles" en España' (28 May 2012) Elpais.com.

5 The arrival of 3,305 people from Syria to Ceuta and Melilla in 2014 marked a new trend that has increased migration flows in Ceuta and above all, in Melilla. See Spanish Ministry of the Interior, 'Balance 2014 Lucha contra la Inmigración Irregular', 9 http://www.interior.gob.es/documents/10180/3066430/Balance+2014+ $\mathrm{de}+$ la + lucha + contra + la + inmigraci $\% \mathrm{C} 3 \% \mathrm{~B} 3 \mathrm{n}+$ irregular/4a33ce71-3834-44fc-9fbf -7983ace6cec4 accessed 5 April 2019. This number rose to 7,189 in 2015, a much higher figure than that for other nationalities arriving in Ceuta and Melilla that year (a total of 4,435, mostly from sub-Saharan Africa). See Spanish Ministry of the Interior, 'Balance 2015 Lucha contra la Inmigración Irregular', http://www.interior.gob.es/ documents $/ 10180 / 3066430 /$ Balance $+2015+$ de + la + lucha + contra + la + inmigraci $\%$ C3 \%B3n+irregular.pdf/d67e7d4b-1cb9-4b1d-94a0-9a9ca1028f3d accessed 5 April 2019.

6 According to the above-mentioned 2014 report: 'In 2014 there were close to 19,000 assaults on the fences at Melilla (350 per cent more than in 2013). Thanks to deterrent measures and to the work of the State Security Forces, 90 per cent of the assailants did not enter Ceuta or Melilla' (ibid., 10).

7 In 2015, attempts to assault the border fences at Ceuta and Melilla fell by 67.8 per cent, while entries to both cities using this method dropped by 78 per cent. Ibid., 11 . 
Libya and Italy $^{8}$ and the consequent decline in maritime immigration by this route, and with 'less surveillance' along the Moroccan coast, which some NGOs have attributed to the unrest in the Rif region that Morocco has witnessed in recent months. ${ }^{9}$

However, a comparison between data on maritime immigration in 2006 (with 39,180 immigrants: 31,678 to the Canary Islands and 7,502 to the Peninsula and Balearic Islands) and more recent data shows that by 2015, the percentage of immigrants arriving in Spain via this route had fallen by 97.2 per cent in the Canary Islands (with the arrival of 875 immigrants) and 40.8 per cent in the rest of Spain (with 4,437 immigrants). ${ }^{10}$ These figures reflect the changes in border control and migration flow management triggered by the 2006 cayucos crisis and implemented by Spain in conjunction with the countries of origin and transit of immigrants primarily from sub-Saharan Africa.

In the first section below, the main immigration routes (sea and land) to Spain used by human trafficking mafias will be analysed, paying particular attention to the drop in maritime immigration to the Canary Islands following the 2006 cayucos crisis. This decline has been due to Spanish cooperation with third countries (mainly Morocco, Senegal and Mauritania) and institutional cooperation within the EU, both of which have served to reduce migration flows across the Atlantic, but have also spurred the quest for new routes of entry to Spain through Spanish territories in North Africa.

The second section will be focused on the arrival of immigrants in the autonomous cities of Ceuta and Melilla and to Spanish islands and islets in North Africa. In both cases, the Spanish practice of summary returns has aroused criticism. Although the Spanish Government adopted a new legal framework in 2015 with respect to the special regime of Ceuta and Melilla aimed at providing a legal basis for these returns (for example, rejection at the border), this would not be applicable to immigrants who arrive by swimming to these cities, nor to those arriving in boats to Spanish islands and islets off the Moroccan coast.

To conclude is a discussion of the economic measures that Spain and the EU have adopted in the field of development cooperation with the aim of improving conditions in countries of origin that encourage their citizens to seek a better, 'safer' life on the European continent.

8 'Por qué España vuelve a ser ruta principal para los inmigrantes que buscan entrar en Europa por el Mediterráneo?' (21 August 2017) BBC Mundo and 'La crisis migratoria llega a España’ (6 September 2017) https://es.gatestoneinstitute.org/10950/ crisis-migratoria-espana accessed 5 April 2019.

9 'La ruta española de pateras alcanza cifras de 2008' (14 September 2017) Elpais. com.

10 Spanish Ministry of the Interior, 'Balance 2015 ' (n 5) 5-6. 


\section{SEA AND LAND IMMIGRATION ROUTES TO SPAIN: COOPERATION WITH THIRD COUNTRIES TO FIGHT IRREGULAR IMMIGRATION}

There are two main routes into Spain for immigrants seeking to enter irregularly. ${ }^{11}$

One is the West African route, which encompasses sea crossings to the Canary Islands from countries such as Senegal, Mauritania and Morocco. The main countries of origin of the immigrants and refugees who use this route are Morocco, Senegal, Niger, Nigeria and Mali: in 2017, the majority of arrivals (a total of 133 from January to September) corresponded to nationals from Morocco (55), Guinea (37) and Ivory Coast (17).

The decline in immigration by this route, which in 2012 reached its lowest figures yet with 173 immigrants, ${ }^{12}$ has been due to agreements on the deployment of Spanish and EU sea and air patrols in the waters of these African countries; to the efforts of the Spanish police and authorities in the field of repatriation; and to increased police cooperation in Africa, which has led to an increase in detentions on land and the consequent dismantling of mafia networks operating there. ${ }^{13}$

Of particular note has been the creation of joint Spanish and Moroccan patrols as a result of bilateral agreements on immigration signed by Spain and Morocco at the Marrakesh Summit held on 8 and 9 December 2003. The first patrol, launched in February 2004, consisted of members of the Spanish Civil Guard Naval Service and the Royal Moroccan Gendarmerie. Initially, two civil guards patrolled Moroccan vessels in the area of Laayoune, but following the Marbella Summit in January 2004, this was extended to the area around the Strait of Gibraltar and the Atlantic region (Las Palmas, Laayoune, Algeciras-Tangiers and Nador-Almeria). ${ }^{14}$

11 http://Frontex.europa.eu/trends-and-routes/migratory-routes-map/ accessed 5 April 2019.

12 Spanish Ministry of the Interior, 'Balance 2015 ' (n 5) 8.

13 Francisco Javier Vélez Alcalde 'Pateras, cayucos y mafias transfronterizas en África: el negocio de las rutas atlánticas hacia las Islas Canarias' (ARI No 14/2008, 5 February 2008) Real Instituto Elcano 6.

14 Miguel A. Acosta Sánchez and Alejandro del Valle Gálvez, 'La crisis de los cayucos. La Agencia Europea de Fronteras FRONTEX y el control marítimo de la inmigración clandestina' (2006) 83 Tiempo de Paz 19-30. 
The creation in 2002 of the Integrated External Surveillance System (Spanish abbreviation: SIVE) $)^{15}$ and the Spanish-Moroccan police cooperation launched in 2004 together prompted human trafficking mafias to seek a more southerly destination, the Canary Islands, which at the end of 2005 witnessed the first avalanche of immigrants.

Since the beginning of the cayucos crisis, the Spanish Government has adopted various operational measures to combat new routes of irregular immigration. Thus, in March 2006, an agreement was reached with Mauritania to create joint patrols (operation Cabo Blanco), and the Mauritanian gendarmerie was given four patrol boats and training for the staff that would be working on them. In Spain, military buildings were equipped to receive immigrants and the Canary Islands security forces were strengthened. It was also agreed to extend the SIVE system to Tenerife. In addition to these measures, on 28 July 2006, the Council of Ministers adopted the 2006-08 Comprehensive Security Plan for the Canary Islands. Finally, to further strengthen existing measures, on 10 October 2006, the Council of Ministers approved the agreement establishing the creation of the Canary Islands Regional Coordination Centre (Spanish initials: CCRC), which incorporated the Frontex Coordination and Control Centre (FCCC).

The need for a combined and comprehensive European strategy to combat irregular immigration, with economic and material support from the EU, led the Spanish Government to bring this matter before its European partners. As a result, in May 2006 Spain spearheaded a working group to strengthen the control of irregular immigration from Africa. At a meeting held in Madrid on 29 May 2006 under the direction of Frontex and with the equal participation of the European Commission and Europol, Member States reached an agreement to launch a joint operation in the area of origin of immigrant boats. Spain,

15 The SIVE is an operational system with technical support that provides real-time information to a control centre which then issues the necessary orders to intercept any element approaching national territory from the sea. The prototype centre is based in Algeciras and covers the entire Strait of Gibraltar area. This system uses cutting-edge technology (a complex network of mobile and fixed sensors) to detect small boats departing from Morocco, and is capable of accurately detecting the smallest boats on North African beaches, even under adverse conditions. The effectiveness of this system, which has enabled Spanish security forces to promptly detect and detain boats before their arrival onshore, rapidly created the need to seek other landing places. Subsequently, this system was gradually extended to cover the provinces of Cadiz, Malaga and Granada, the autonomous city of Ceuta and the island of Fuerteventura in the Canary Islands. According to sources in the Spanish Ministry of the Interior (20 August 2008), the Civil Guard has reinforced control of irregular immigration in Cadiz with a new mobile SIVE sensor station, which will monitor the coastline between Barbate and Conil de la Frontera. 
Germany, Austria, Denmark, Estonia, Finland, France, Italy, Norway, the Netherlands, Poland, Portugal and the United Kingdom all offered to collaborate in the operation. European support was further evidenced at the European Council held in Brussels in June 2006, which welcomed the cooperation measures adopted by the Commission, Frontex and some Member States as a result of the situation in the Canary Islands and the Mediterranean. In addition, calls were made to intensify efforts to establish operational maritime cooperation that would enable effective monitoring of maritime borders, and to create rapid border intervention teams.

Frontex coordinated two operations. In the first of these, called Hera I, European experts were deployed to identify irregular immigrants arriving in the Canary Islands and determine their country of origin. The second, known as Hera II, was launched on 11 August 2006 and was aimed at controlling irregular immigration via the Atlantic. This was a humanitarian operation aimed at increasing surveillance of the coasts from which the boats transporting irregular immigrants from Africa to the Canary Islands departed, in order to prevent their departure, or failing that, to intercept the boats in their territorial waters and return the immigrants to the Mauritanian, ${ }^{16}$ Senegalese ${ }^{17}$

16 Thus, Spain reactivated the readmission agreement with Mauritania. See the Agreement on Immigration between the Kingdom of Spain and the Islamic Republic of Mauritania [2003] the Official State Gazette (BOE) No 185, 4 August 2003. On 22 September 2017, the Spanish Council of Ministers approved the signing of a new cooperation agreement with Mauritania to strengthen and reinforce police cooperation between the two countries in the fight against irregular immigration, among other matters. See 'España y Mauritania reforzarán su colaboración en la lucha contra la inmigración irregular y el terrorismo' (22 September 2017) europapress http://www .europapress.es/sociedad/noticia-espana-mauritania-reforzaran-colaboracion-lucha -contra-inmigracion-irregular-terrorismo-20170922151004.html accessed 5 April 2019.

17 In Dakar on 24 August 2006, Senegal and Spain signed a Memorandum of Understanding to combat irregular immigration to Europe from the coasts of Senegal, establishing joint patrols with the Spanish Civil Guard and Senegalese security forces to intercept immigrant boats destined for the Canary Islands. Since then it has been extended, as in 2009, when the Memorandum of police cooperation was signed with Mauritania. See Ministry of the Interior, 'Firma de dos Memorandos de cooperación policial con Senegal y Mauritania [Signing of two Memoranda on police cooperation with Senegal and Mauritania]' (Press release 3 November 2009). Recently, Spain and Senegal have signed a joint declaration, which will lead to the negotiation of a new Memorandum of Cooperation between the two countries. See Ministry of the Interior, 'España y Senegal acuerdan intensificar la cooperación bilateral para luchar contra el terrorismo, el crimen organizado y el narcotráfico, y reforzar la gestión de los flujos migratorios [Spain and Senegal have agreed to intensify bilateral cooperation to combat terrorism, organised crime and drug trafficking, and to strengthen migration flow management]' (Press release 20 July 2017). 
or Cape Verde authorities. The operation was subsequently extended to Guinea-Bissau. ${ }^{18}$ Furthermore, it was in line with the July 2007 Rabat Action Plan for a Euro-African Partnership on Migration and Development. The initial duration of Hera II was between eight to nine weeks, but was subsequently extended through new dispositions.

Also of note was the Seahorse Project (2006-08) adopted by the European Commission and spearheaded by Spain. The specific objectives of this project ${ }^{19}$ were to establish an effective policy in the countries affected to prevent irregular immigration, which would include efforts to stop human trafficking; to establish and develop relations between the Maghreb and sub-Saharan Africa, and foster dialogue on migration issues; to promote regional collaboration and dialogue on migration flow management, including transit and migration, irregular immigration and human trafficking; to provide training for staff dealing with migration issues; and to assess and improve the capacity to implement border control through operational cooperation.

This project was later enhanced by the creation of the Seahorse Network (2007-08), which established a secure satellite information exchange network, with local points of contact in Mauritania, Cape Verde, Senegal and Portugal, and a South Atlantic Border Cooperation Centre in Las Palmas. Seahorse Project Cooperation Centres (2009-10) transformed the points of contact into coordination centres similar to the CCRC.

In the context of these projects, many actions were carried out in Morocco, Senegal, Mauritania, Gambia, Guinea-Bissau, Cape Verde, Portugal and Spain between 2006 and 2010. Lastly, a communications network (Seahorse Atlantic) was created with a centre in each of the participating countries (except for Mauritania, which has two) to enable operational coordination and permanent and secure information exchange via satellite. ${ }^{20}$

In order to consolidate relations and cooperation with these countries, in late 2010 the European Commission launched the West Sahel Project (2011-16), whose beneficiaries would be the countries in the Western Sahel, mainly Mauritania, Senegal, Mali and Niger, with the participation in some activities of Cape Verde, Gambia, Guinea-Bissau, the Republic of Guinea and Burkina Faso. All these projects have subsequently continued within the context of

18 Due to the greater control exercised in Senegal, immigrant boats bound for the Canary Islands began to depart from the even more distant Guinea Bissau.

19 See 'VI Conferencia euro-africana sobre inmigración irregular' (18 October 2011), http://www.guardiacivil.es/es/prensa/noticias/historico2/3220.html accessed 5 April 2019.

20 See Spanish Ministry of the Interior, 'El Director General de la Policía y de la Guardia Civil asiste a la reunión del Proyecto Seahorse sobre control de la inmigración irregular por vía marítima' (15 December 2010). 
the proposal put forward by Spain, the Blue Sahel Project (2017-19), aimed at coordination between the Spanish Civil Guard and the authorities of seven countries in the Sahel region to combat irregular immigration, drug trafficking and terrorism. The project consists of creating cross-border patrols and intelligence units, as well as training actions and cooperation with these countries.

These projects and Spain's bilateral cooperation with Mauritania and Senegal have virtually closed the sea route from West Africa for immigrants from these countries.

However, Amnesty International has denounced the practice of summary expulsion $^{21}$ (for example, the summary return of undocumented immigrants without respecting due process or these immigrants' human rights), in relation to the readmission agreement that Spain signed with Mauritania in 2003. Spain had signed agreements with Morocco, Algeria, Mauritania and Guinea-Bissau to return irregular immigrants intercepted at sea, ${ }^{22}$ and after the cayucos crisis, also with Ghana, Cape Verde, the Republic of Guinea, Mali, Gambia, Niger and Senegal. It is interesting to note that several of these agreements provide for the possibility of joint border control patrols in waters under the sovereignty or jurisdiction of the third state (for example, the agreement with Cape Verde), with the implicit support of Frontex. This entails the participation of members of the Spanish Civil Guard on Spanish and third-country vessels, performing border control tasks in maritime areas under the sovereignty or jurisdiction of a third state. The purpose is to prevent the launch of Europe-bound vessels carrying irregular immigrants and return these to their point of origin, even if they are nationals of the third state.

Thus, border guards from Member States are carrying out surveillance tasks beyond the European borders defined in the Schengen Borders Code, in order to control and prevent the arrival - or even the mere approach - of irregular immigrants to Europe's external maritime borders. In this sense, the UN Committee against Torture (subject matter: Detention of 23 Indian immigrations in Mauritania under Spanish control), considered in 2008 that the jurisdiction of a state party 'must also include situations where a State party exercises, directly or indirectly, de facto or de jure control over persons in detention'. The Committee observed that Spain maintained control over the

21 See Amnesty International, 'Mauritania: "Nadie quiere tener nada que ver con nosotros". Arrestos y expulsiones colectivas de migrantes a quienes se ha negado la entrada en europa' (Report 2008). See also 'España "obliga" a Mauritania a arrestar y expulsar de forma colectiva a los inmigrantes’ (1 July 2008) Elmundo.es.

22 On the complex and varied legal nature of these Agreements and Memoranda of Understanding, see Alejandro del Valle Gálvez, 'Mesures nationales sur le trafic illégal de personnes et la criminalité transnationale organisée' in José Manuel Sobrino Heredia (ed.), Sûreté maritime et violence en mer (Bruylant 2011) 19-28. 
persons on board the cargo vessel Marine I from the time it was rescued in international waters and throughout the identification and repatriation process of the immigrants. The 23 alleged victims, who refused to sign voluntary repatriation agreements, remained in detention under Spanish control in Nouadhibou (Mauritania) in a former fish-processing plant. The Committee observed that Spain exercised, 'by virtue of a diplomatic agreement concluded with Mauritania, constant de facto control over the alleged victims during their detention in Nouadhibou'. ${ }^{23}$

Meanwhile, the Western Mediterranean route encompasses the Moroccan-Spanish area and includes both sea and land routes. A decade ago, immigrants using this route mainly came from Morocco and Algeria, but these have now been joined by nationals from war-torn countries such as Mali, Sudan, South Sudan, Cameroon, Nigeria, Chad and the Central African Republic, among others. In recent years, it has also been used by people from Syria, who in 2015 formed the most numerous group, with 7,189 immigrants compared with 3,305 in the previous year. Between January and August of 2017, 13,364 immigrants were recorded, almost double the number from the previous year (7,888 from January to October 2016), mostly from Morocco $(2,758)$, Ivory Coast $(2,347)$ and Guinea $(1,811) .{ }^{24}$

Spain has also strengthened bilateral cooperation on this route with the countries of origin and transit, as mentioned earlier, as well as cooperation within the framework of the EU and the G6.

Major actions include the Seahorse Mediterranean Project, ${ }^{25}$ approved by the European Commission in 2013 for a period of three years, with the participation of Spain, France, Italy, Malta, Portugal, Cyprus, Greece and Libya.

In addition, at a meeting of Interior Ministers of the G6 (Germany, Poland, Spain, France, the UK and Italy) held on 6 November 2014, Spain reiterated its commitment to strengthening the border control and migration management capacities of both the EU and the countries of origin and transit, as well as the operational capacities of Frontex. The Spanish Minister highlighted the three Frontex maritime operations led by Spain (Indalo and Minerva in the Mediterranean and Hera in Senegalese waters, this being a unique case since it is the only Frontex operation in African waters), and reaffirmed Spain's commitment to continue providing material and human resources, in this case in

23 Decision of the Committee against Torture, 41st session, 3-21 November 2008 Decision, Communication No 323/2007, CAT/C/41/D/323/2007 (21 November 2008) accessible in https://www.ohchr.org/EN/pages/home.aspx accessed 5 April 2019.

${ }_{24} \mathrm{http} / / /$ Frontex.europa.eu/trends-and-routes/migratory-routes-map/ accessed 5 April 2019, and Spanish Commission for Refugee Aid (n 3) 9-10.

25 http://www.interior.gob.es/prensa/noticias/-/asset_publisher/GHU8Ap6ztgsg/ content/id/1827498 accessed 5 April 2019. 
the Triton operation in Italy. As particularly effective measures to strengthen the border control and migration management capacities of the countries of origin and transit, Spain proposed the establishment of joint investigation teams with these countries, and the coordination of return actions with Frontex and the International Organization for Migration (IOM).

Furthermore, at the meeting of the G6 held in Seville on 16 October 2017, with the participation of senior representatives of the Interior from the EU and Morocco, the Interior Ministers agreed to strengthen cooperation with key countries in the fight against irregular immigration, such as Morocco, Mauritania, Senegal, Niger and Libya, with the aim of countering immigration pressure on the Mediterranean. At this meeting, the five cornerstones of cooperation on immigration were defined: prevention at source through cooperation with countries of origin and transit; operational projects on the ground; the fight against human trafficking networks; border control; and return. To achieve these objectives, concrete measures were envisaged to prevent the movement of irregular immigrants, such as assisting in capacity-building for border control in sub-Saharan Africa and the Sahel; providing technical assistance to monitor sea and land borders; continuing to facilitate economic and social development on immigration routes, creating a sustainable alternative for immigrants in countries of origin and transit; and supporting the work of the UNHCR and IOM.

Lastly, it should be noted that depending on the origin of the immigrants, two methods are used to enter Spain via Ceuta and Melilla: one is to enter at border posts and the other by 'assaulting' these posts or the border fences surrounding Spanish territory in North Africa. Sub-Saharan African immigrants do not have access to Spain via border posts, so assaults on border fences are relatively common and have been accompanied by the Spanish practice of summary returns. This policy dates back to 2005 and has continued ever since, and has also been employed following the arrival of immigrants by sea to Spanish islands and islets in North Africa or by swimming to the beaches of the above-mentioned autonomous cities. ${ }^{26}$

26 See Inmaculada González García, 'El Acuerdo España-Marruecos de readmisión de inmigrantes y su problemática aplicación: Las avalanchas de Ceuta y Melilla' (2006) 22 Anuario Español de Derecho Internacional 255-84; Inmaculada González García, 'La llegada de inmigrantes a Isla de Tierra en Alhucemas: Crisis migratoria entre España y Marruecos y violaciones de Derechos Humanos' (2014) 27 Revista Electrónica de Estudios Internacionales 1-28; and Inmaculada González García, 'Rechazo en las fronteras exteriores europeas con Marruecos: Inmigración y derechos humanos en las vallas de Ceuta y Melilla, 2005-2017' (2017) 43 Revista General de Derecho Europeo 17-57. See also the legal reports issued by the IUSMIGRANTE $\mathrm{R}+\mathrm{D}+\mathrm{i}$ Project (Iuspuniendi e inmigración irregular) (DER 2011-26449), coordinated by Margarita Martínez Escamilla, “Expulsiones en caliente”. Cuando el Estado actúa 
This procedure is only possible thanks to cooperation between Spain and neighbouring Morocco, since the latter is the main point of departure for immigrants arriving in Spain by the West Mediterranean route. ${ }^{27}$ Cooperation on immigration is one of the main areas of Spanish-Moroccan relations; in contrast, within the framework of EU-Morocco relations, ensuring respect for human rights has always played a major role. ${ }^{28}$ This is reflected in the EU's readmission agreements with third countries, and in particular with Morocco, whose fifteenth round of formal negotiations was held on 10 May 2010. ${ }^{29}$

al margen de la ley' (27 June 2014, last modification on 18 April 2016) http://eprints .ucm.es/25993/ accessed 17 March 2020, 1-21, and "'Rechazos en frontera”: ¿Frontera sin derechos? Análisis de la disposición adicional décima de la Ley Orgánica 4/2000, de 1 de enero, sobre derechos y libertades de los extranjeros en España y su integración social, introducida por la Ley Orgánica 4/2015, de 30 de marzo, de protección de la seguridad ciudadana' (13 April 2015) http://eprints.ucm.es/29379/ accessed 17 March 2020, 1-34.

27 It should be noted that in the words of S. Zebda, cooperation in this area is excellent, mainly following the creation of joint patrols in 2004, the exchange of liaison and information officers and the signing of the 2012 Agreement on the creation of Spanish-Moroccan Police Cooperation Centres to coordinate the fight to prevent irregular immigration, among other goals. To this end, the Spanish Government has tripled spending on police cooperation with Morocco to increase control of the Southern border. In 2012, 33,637 euros were allocated to border surveillance cooperation, a figure which by 2014 had risen to 108,733 euros. See 'XI Reunión de Alto Nivel hispano-marroquí, junio de 2015: reflexiones sobre la cooperación en economía, seguridad y cultura' (2015) 3 Paix et Securité Internationales 227, 232.

${ }_{28}$ See 'Joint Declaration published after the EU-Morocco Summit', Granada, 7 March 2010, 7220/10 (Presse 54), 10 March 2010.

29 European Commission, 'Staff working document accompanying the Communication from the Commission to the European Parliament and the Council, Evaluation of the EU Readmission Agreements, EU Readmission Agreements: Brief overview of State of Play' SEC (2011) 209 3-4. See 'Bruselas, en dificultades para avanzar acuerdos de readmisión de inmigrantes con países norteafricanos' (2 February 2017) Europa Press, including Morocco (whose negotiation has been blocked to date), Algeria, Tunisia and Jordan, in http://www.europapress.es/internacional/noticia -bruselas-dificultades-avanzar-acuerdos-readmision-inmigrantes-paises-norteafricanos -20170202151737.html accessed 5 April 2019. 
III ENTRY TO SPAIN VIA CEUTA, MELILLA AND SPANISH ISLANDS AND ISLETS IN NORTH AFRICA: THE 1992 SPANISHMOROCCAN AGREEMENT ON READMISSION OF FOREIGNERS WHO HAVE ENTERED IRREGULARLY

Below, the distinctive features of border control and migration flow management on the West Mediterranean route will be analysed in terms of entry to Spanish territories in North Africa. In 2015, the Spanish Government adopted a new 'procedure' with respect to the special regimen of Ceuta and Melilla, consisting of rejection at the border, ${ }^{30}$ in order to provide a legal basis for the practice of summary returns. However, in its judgment of 3 October 2017, the European Court of Human Rights (ECHR) condemned Spain for this practice, in this case for having summarily returned two sub-Saharan Africans (from Mali and Ivory Coast) who had managed to scale the border fence at Melilla on 13 August 2014. ${ }^{31}$

\section{A The Special Regime of Ceuta and Melilla: From an Operational Concept of Borders to Rejection at the Border}

The border fences surrounding Ceuta and Melilla demarcate the land border of Spain, and therefore the external borders between the EU and Morocco. Consequently, Spanish procedures for the return, expulsion or readmission of immigrants seeking to enter the Schengen area irregularly must respect human rights.

Until 1996, the borders of Ceuta and Melilla were protected by a wire fence in Ceuta (from 1993) and a military fence in Melilla (from 1971). However, between 1996 and 1999, the Spanish Government ordered the border with Morocco to be reinforced, and two parallel fences were erected enclosing an inner road for border surveillance. At the same time, the height of the fences was increased from three metres in 2006 to six metres. That same year, while Spain was building a fence around the breakwater on the El Tarajal beach in Ceuta, Morocco was also digging a trench parallel to the fence outside the city, like the one already existing alongside the fence in Melilla. It was also agreed to raise a third fence or three-dimensional barrier in both cities, which was only

30 We question the appropriateness of this new 'procedure', which to date (two years after its entry into force) has still not passed into the Aliens Regulation (n 36).

31 N.D. et N.T. v Spain, Apps Nos 8675/15 and 8697/15 (ECHR, 3 October 2017). 
erected in Melilla between the two already existing fences, reaching a height of two metres. Since 2014, further reinforcements have been made to this fence.

However, the layout of these fences does not coincide with Spain's conception of them as being 'for the sole purposes of immigration'. Although the legal concept of the border 'is in accordance with the international treaties entered into between the kingdoms of Spain and Morocco', the functional or operational concept of the same 'seems to respond to a political criterion of the Government, or to a simple police operation', ${ }^{32}$ as it effectively facilitates the criticized summary returns that have been carried out by the Spanish security forces since 2005 against immigrants who become trapped between the Ceuta or Melilla border fences or who have swum to these cities, because once these have crossed the inner fence or the line formed by the civil guards waiting on the beach, they are deemed irregular immigrants on Spanish soil. ${ }^{33}$

Indeed, the sad episode on 6 February 2014, when members of the Civil Guard returned 23 immigrants who had swum to Ceuta's El Tarajal beach in Morocco (with another 15 immigrants drowned in Moroccan waters), clearly evidenced the concept of operational border used by the Spanish security forces. The Minister of the Interior, Mr Fernández Díaz, appeared in the Congress of Deputies on 13 February 2014 to defend the actions of the Civil Guard in applying this operational concept of the border, ${ }^{34}$ basing his argument on 'the unique characteristics of border control' in Ceuta and Melilla.

According to a ruling on 11 September 2014 of the Court of First Instance and Preliminary Investigation No 2 in Melilla, the Civil Guard also used this concept of an operational or functional border when on 18 June and 13 August 2014 an undetermined number of immigrants who had scaled the outer fence at Melilla and were in the space between the last two fences, or were on the upper part of the inner fence at Melilla, respectively, were handed over to the Moroccan authorities. This concept of land border that the Civil Guard applies to the border fence at Melilla implies that ' ... the inner fence embodies the line that defines Spanish territory, for the sole purposes of immigration' ${ }^{35}$

32 See the ruling of the Court of First Instance and Instruction No 2 of Melilla of 11 September 2014, Court Consideration No 3.

33 Martínez Escamilla, 'Rechazos en frontera' (n 26) 14.

34 The operational concept of border used by the Ministry of the Interior appears in the report of 8 February 2014 drawn up by the Civil Guard Deputy Directorate for Operations and addressed to its Directorate General, concerning the events on El Tarajal beach. The report was delivered by the Ministry of the Interior to the Congress of Deputies on 7 March 2014. Ibid., 14 and Martínez Escamilla, 'Expulsiones en caliente' (n 26) 6.

35 Concept applied to the fence in Melilla, according to the report of the Civil Guard of the Autonomous City (submitted on 2 September 2014 to the Court of First Instance and Instruction No 2 in Melilla, Court Consideration No 2.7 of the ruling adopted by 
In response to widespread criticism of the practice of summary returns and the numerous complaints lodged before national and international courts as being contrary to the provisions of Spanish-Moroccan border treaties and international law on human rights, the Spanish Government introduced a series of partial amendments to the organic law on the protection of citizen security in order to 'legalize' the practice. The tenth additional provision in the Aliens Act (Spanish initials: LOEx) ${ }^{36}$ incorporates 'rejection at the border' in the following terms:

Special regime of Ceuta and Melilla:

1. Foreigners detected at Ceuta's and Melilla's borders trying to pass the border barriers and cross the border illegally can be rejected to avoid their illegal entry into Spain.

2. These rejections will be implemented respecting the international law on human rights and international protection ratified by Spain.

3. International protection claims will be formalized at the places designated to this effect at border posts in line with international protection obligations.

However, in its attempt to provide a legal basis for summary returns through rejection at the border, the Spanish Government forgot that the unique characteristics of Ceuta and Melilla were already covered by Spanish legislation on immigration.

Thus, the LOEx and its Regulation (RLOEx) ${ }^{37}$ already regulate the procedures for 'refusal of entry' at a designated border post when the person concerned does not have the required documentation and does not meet the requirements laid down in article 25 of the LOEx to enter Spanish territory, as well as those for the 'expulsion' and 'return' of aliens.

Expulsion occurs when a foreigner commits an offence classified as very serious or serious in the $\mathrm{LOEx}^{38}$ and applies to cases in which the foreigner is already on Spanish soil.

But under the terms of article 58(3)(b) of the LOEx, an expulsion order is not necessary for the return of foreigners intending to enter Spain irregularly,

said Court on 11 September 2014), which refers to the Order of Service 6/2014 entitled 'Dispositivo anti intrusión en la valla perimetral de Melilla y protocolo operativo de vigilancia de fronteras', signed by the Colonel-in-Chief of the Civil Guard Command in Melilla on 11 April 2014.

36 Organic Law 4/2000, on the rights and freedoms of foreigners in Spain and their social integration (BOE No 10, 12 January 2000).

37 Royal Decree 557/2011, of 20 April, which approves the Regulation of Organic Law 4/2000, on the rights and freedoms of foreigners in Spain and their social integration, following its amendment by Organic Law 2/2009 (RLOEx). BOE No 103, 30 April 2011.

38 Article 57(1) LOEx. 
which includes foreigners who are intercepted at or nearby the border, under the terms of article 23(1)(b) of the RLOEx. Regardless, the return shall be decided by the governing authority responsible for expulsion, which in the case of single province autonomous communities is the Government Delegate. ${ }^{39}$

Consequently, this return procedure renders rejection at the border unnecessary. The provisions of the RLOEx also establish procedural safeguards, indicating that when the state security forces responsible for guarding coasts and borders intercept such foreigners, they should conduct these as soon as possible to the corresponding police station of the National Police for identification and, where appropriate, return. ${ }^{40}$ These safeguards are also intended to ensure respect for their human rights, expressly recognizing their right to legal assistance, and an interpreter where necessary, in accordance with article 23(3). They furthermore provide for the possibility of requesting the legal authorities for permission to intern the immigrant in an immigration detention centre (Spanish initials: CIE) in the event that a return cannot be executed within 72 hours. ${ }^{41}$

Applying the legal concept of border in the terms agreed by Spain and Morocco for Ceuta and Melilla (whose borders are represented by fences, where the outer fence is the border between Spanish territory and the neighbouring country), any immigrant trapped within the double/triple border fence, found climbing a fence or who has managed to scale them and is detained in their vicinity falls under Spanish jurisdiction and sovereignty for the purposes of immigration, because the fences are Spanish and are built on Spanish soil.

This is contrary to the provisions of paragraph 1 of the tenth additional provision of the LOEx, in which the operational concept of border is implicit. Therefore, we can conclude that the new procedure of rejection at the border not only violates the procedural safeguards established by Spanish law on immigration, but also breaches international treaties on human rights to which Spain is a party. This contravenes explicit recognition in paragraphs 2 (human rights) and 3 (international protection) of the tenth additional provision of the LOEx, indicating that written provisions do not guarantee compliance in practice.

Rejection at the border is intended for application to immigrants seeking to enter Ceuta and Melilla irregularly by climbing over the border fences (thus differentiating between rejection at the border and refusal of entry at the border post), but paragraph 2, which stipulates that such rejection should respect international human rights and international protection, is contingent on application

Article 58(5) LOEx.

Article 23(2) RLOEx.

Article 58(4) LOEx and article 23.4 RLOEx. 
for international protection being formalized at the places designated to this effect at border posts. However, as has been reported, sub-Saharan immigrants have no access to these border posts due to repression from the Moroccan authorities. $^{42}$

\section{B Human Rights in Return Procedures}

National immigration laws, Spanish ones included, are constrained by international customary and treaty law, which imposes limits intended to ensure respect for the dignity of human beings, this being the minimum standard of international protection accorded to foreign nationals, including irregular immigrants. Special mention should be made of the provisions concerning protection of the right of asylum and subsidiary protection, and in particular, of compliance with the provisional guarantees of entry and stay granted to foreigners by the receiving state, and the principle of non-refoulement.

Focusing on the right to seek asylum, irregular entry into Spanish territory cannot be punished, according to Spanish domestic law, when such entry has been effected by foreign nationals who meet the requirements to qualify for the status of refugees, provided they present themselves without delay to the authorities. In this case, expulsion or return should be suspended from the moment the foreign national requests the protection conferred by asylum until a decision is issued on the application admitted for processing. ${ }^{43}$

Moreover, this right is recognized in the Geneva Convention of 28 July 1951 on the status of refugees, in its Protocol of 31 January 1967, of which Spain is a party, ${ }^{44}$ and in EU law.

Thus, the Directive on returns establishes several procedural guarantees for nationals of third countries subject to return ${ }^{45}$ (including respect for the principle of non-refoulement), in accordance with fundamental rights and, in particu-

42 See the Servicio Jesuita a Migrantes-España, 'Vidas en la Frontera Sur' (Report 17 July 2014) and Servicio Jesuita a Migrantes-España, 'Sin protección en la frontera. Derechos humanos en la frontera sur: Entre Nador y Melilla' (Report 22 May 2016).

43 Article 23(6)(b) RLOEx and article 58(4) LOEx.

44 The State of Morocco is also party to the Geneva Convention and its Protocol, since 1956 and 1971, respectively.

45 Directive (EC) 2008/115 of the European Parliament and of the Council of 16 December 2008 on Common Standards and Procedures in Member States for Returning Illegally Staying Third-country Nationals [2008] OJ L348/98 (Returns Directive), transposed into Spanish domestic law by Organic Law 2/2009, of 11 December, on the amendment of Organic Law 4/2000, of 11 January, on the rights and freedoms of foreigners in Spain and their social integration, BOE No 299, 12 December 2009. Chapter III (articles 12-14) provides for a procedure documented in writing, with the possibility of appeal and with the assistance of counsel and an interpreter. 
lar, the EU Charter of Fundamental Rights (EUCFR). These include respect for human dignity; the right to life; the prohibition of the torture and inhuman or degrading treatment or punishment; the prohibition of trafficking in human beings; the right to liberty and security; the right of asylum and protection against repatriation and expulsion; and the principle of non-refoulement.

Hence, EU-third country readmission agreements cannot be applied to persons who might be subject to persecution, torture or inhuman or degrading treatment or punishment in the country of return, nor can they be applied in these cases to citizens of third countries (who are not nationals of any of the parties), pursuant to the third-country nationals (TCNs) clause contained in all readmission agreements.

In the present case, the EU-Morocco Agreement on mobility (EU-Morocco Mobility Partnership), signed on 7 June 2013, includes the TCN clause, thus establishing respect for human rights, in order to strengthen collaboration in the management of migration and mobility of Moroccan citizens.

On the other hand, fundamental rights (for example, the right to life and the physical or moral integrity and legality of foreign nationals who are under the jurisdiction of a state) must be observed and ensured in expulsion/return procedures. This is indicated in ECHR case-law and the guidelines on forcible returns issued by the Committee of Ministers of the Council of Europe, which prohibit collective expulsion orders and stipulate the individual examination of each case and the adoption of individual decisions on return. It should also be borne in mind that in 2009, Spain ratified Additional Protocol 4 of the Rome Convention (1950) for the protection of human rights and fundamental freedoms, which prohibits the collective expulsion of foreign nationals. According to the interpretation made in ECHR case-law, this represents a prohibition in the qualitative rather than quantitative sense of the term, since its determining feature is not that it falls on a more or less numerous group of people, but that it 'does not guarantee the possibility of making allegations or recording who the expelled person is or if the person needs any special protection' ${ }^{46}$

In fact, within the framework of the Council of Europe, on 30 July 2015, the ECHR asked the Spanish Government for an explanation of the summary returns carried out on 13 August 2014, following the actions brought by two sub-Saharan Africans (from Mali and Ivory Coast) who had managed to climb over the border fence at Melilla. ${ }^{47}$

Lastly, in the aforementioned judgement on this issue of 3 October 2017, the ECHR ruled that Spain had violated article 4 of Protocol 4, which prohib-

See Martínez Escamilla, 'Rechazos en frontera' (n 26) 27.

$47 \mathrm{http} / /$ www.statewatch.org/news/2015/aug/echr-spain-hot-returns-decision-fr .pdf accessed 5 April 2019. 
its the collective expulsion of foreign nationals, and article 13 of the Rome Convention, which recognizes the right to an effective remedy, made in relation to article 4 of Protocol $4 .^{48}$

\section{Validity of the Spanish-Moroccan Agreement on Readmission of Foreigners Who Have Entered Irregularly}

Having questioned the legality and expediency of the new concept of rejection at the border, in line with the argument that the unique characteristics of Ceuta and Melilla are already contemplated in the Spanish law on aliens (articles 58(3)(b)) of the LOEx and 23(1)(b) of the RLOEx), once the return of immigrants has been decided by resolution of the Government Delegate in Ceuta and Melilla, this would be implemented under the terms laid down in the 1992 Spanish-Moroccan Agreement on readmission of foreigners who have entered irregularly, the validity of which has not yet been questioned. ${ }^{49}$ This agreement allows the border authorities in Ceuta and Melilla to respect human rights and ensure compliance with the legislation on asylum and subsidiary protection.

Therefore, the return of sub-Saharan immigrants should be implemented in accordance with the provisions of Chapter I on 'readmission of foreign nationals'. The scope of this agreement is limited to nationals of third countries, who would be readmitted by the Moroccan border authorities at the formal request of the Spanish State, when they have irregularly entered Spanish territory from Morocco. This thus envisages the possibility of readmission of sub-Saharan African immigrants found trapped between the fences, climbing a fence or located in their vicinity, in compliance with the provisions of article 2. According to this provision, readmission shall be made if it can be proven by any means that the foreign national whose readmission is sought has come from Moroccan territory. This is easy to prove in the case of those who have swum from Morocco to Ceuta or Melilla.

Once the return of immigrants has been decided by resolution of the Government Delegate in Ceuta or Melilla, in accordance with the Spanish

48 The ECHR thus recognized the collective nature of the expulsion, highlighting that it was performed in the absence of an administrative or judicial decision and without any procedure on the part of the Spanish authorities to identify the plaintiffs. In this ruling, the ECHR also established a connection between the collective expulsion of the plaintiffs on the border of Melilla and the fact that they were not allowed to present an appeal to the competent authority.

49 Entry into force of the Agreement between the Kingdom of Spain and the Kingdom of Morocco concerning the movement of personnel and the transit and readmission of foreigners who have entered irregularly [1992] BOE n 299, 13 December 2012. 
legislation on immigrants (for example, the provisions of article 58(3)(b) of the LOEx and article 23(1)(b) of the RLOEx), Spain has ten days from the moment of irregular entry into Spanish territory to lodge a request with the Moroccan authorities for their readmission to Morocco, if their right to apply for asylum or subsidiary protection has been denied.

This readmission request should include all available information on the identity and personal documentation of each immigrant and the conditions of their irregular entry into Spanish territory, as well as any other information possessed about each individual. Then, if the request is accepted, the Moroccan border authorities must formalize this by issuing a certificate or other document indicating the identity and, where appropriate, the documents held by the foreign national. Article 3 of the agreement thus ensures compliance with the Spanish legislation on international protection, as it does not provide for the readmission of foreign nationals who have been authorized to remain in Spain after their irregular entry, nor of those to whom Spain has accorded refugee status in accordance with the Geneva Convention of 1951: indeed, if such circumstances are revealed by investigations following their readmission to Morocco, they must be returned to Spain.

Lastly, according to article 5, Morocco shall ensure that returned foreign nationals are sent as soon as possible to their state of origin or to the state where they began their journey, if they do not have the right to remain on Moroccan territory.

Therefore, since the Spanish-Moroccan Agreement on readmission of foreigners who have entered irregularly remains in force, why is it not applied, if it is the procedure for executing the resolution of the Government Delegate in Ceuta and Melilla that authorizes the return?

\section{FINAL ASSESSMENT}

Late 2017 has witnessed a sharp increase in immigration by sea to Spain using the West Mediterranean route, consisting mainly of sub-Saharan Africans and Algerian and Moroccan migrants departing from some point on the Moroccan coast (between Al Hoceima and Nador) and bound for Almeria and Granada. ${ }^{50}$ Nevertheless, despite strengthening the Ceuta and Melilla border fences in recent years, immigrants continue to enter these cities by land, either swimming or during mass assaults on the fences or border posts. This means that close cooperation with Morocco is vital for Spain in the fight against irregular immigration, and this has been achieved despite occasional coolness in relations due to Morocco's claim to Spanish territories in North Africa.

\footnotetext{
50 'Los inmigrantes se lanzan al mar de Alborán' (4 November 2017) Elpais.com.
} 
Since 2005-06, sub-Saharan immigration has been a delicate issue in Spain's bilateral relations with countries such as Morocco, Mauritania or Senegal (in these latter cases, to halt the arrival of immigrant boats to the Canary Islands), and one which requires a much broader approach, both regionally (involving Europe and Africa) and in terms of scope (not solely limited to security issues). In this strategy Spain has since 2006 developed the 'Africa Plans'. ${ }^{51}$

Consequently, following the events in Ceuta and Melilla in 2005, Spain and Morocco took the initiative and the commitment to promote 'triangular' cooperation between countries of origin, transit and destination, ${ }^{52}$ which also took into account the link between migration and development. As a result, a conference on migration and development was held in Rabat on 10 and 11 July 2006, at which participants adopted a political Declaration and a Plan of Action. ${ }^{53}$

This rendered it necessary to develop strategies for development cooperation in the states of origin and formulate policies that would help regulate the arrival of immigrants and their social and occupational integration. ${ }^{54}$ The EU has adopted a new approach and perspective on these issues, as evidenced in the Commission's Green Paper: 'An EU approach to managing economic

51 See María Ángeles Alaminos, 'La política exterior de España hacia África Subsahariana a través del análisis crítico de los Planes África' (2011) UNISCI Discussion Papers; ALBOAN and ENTRECULTURAS, 'Políticas de control migratorio y de cooperación al desarrollo entre España y África Occidental durante la ejecución del primer Plan África' (Report 2011).

52 See Joint Declaration adopted following the meeting of the Ministers of Foreign Affairs and of Cooperation, between the Kingdom of Morocco and the Kingdom of Spain, Madrid-Rabat, 11 October 2005, No 9682 Spanish Ministry of Foreign Affairs and Cooperation (MAEC).

53 See Press release No 117 MAEC (10 July 2006) and Alicia Sorroza Blanco 'La Conferencia Euroafricana de Migración y Desarrollo: más allá del "espíritu de Rabat"' (ARI No 93/2006, 28 August 2006) Real Instituto Elcano de Estudios Internacionales y Estratégicos http://www.realinstitutoelcano.org/analisis/imprimir/ 1028imp.asp accessed 5 April 2019), who indicates the six areas into which the Plan of Action is divided: (1) Migration and development; (2) Legal migration; (3) Illegal immigration; (4) Police and judicial operational cooperation and assistance to victims; (5) Funding; and (6) Institutional and monitoring framework. See also Teresa Fajardo del Castillo 'La Conferencia Ministerial Euro-Africana de Rabat sobre la inmigración y el desarrollo. Algunas reflexiones sobre la política de inmigración de España y de la UE' (2006) 25 Revista de Derecho Comunitario Europeo 913, 924-9.

${ }_{54}$ Alejo Trujillo Marrero, 'La atención en frontera a inmigrantes en situación irregular' in Alejandro del Valle Gálvez and Miguel A. Acosta Sánchez (2005), Inmigración irregular y Derecho (Universidad de Cádiz 2005) 67. 
immigration', ${ }^{55}$ and in the 'EU strategy for Africa: towards a Euro-African pact to accelerate Africa's development'. ${ }^{56}$

Since 2006, Spain has implemented a policy whereby the provision of aid is conditional on fighting irregular immigration. Thus, for example, Mauritania and Senegal have received between 15 and 25 million euros annually since 2006. In total, Mauritania has received 108.45 million, of which 88.6 million have been destined for border control and 19.8 million for development aid. In the case of Senegal, Spanish aid (59.7 million euros in total) has been divided between border control (34.9 million) and development cooperation (24.8 million). This model has also been applied by the EU through the signing in 2016 of the so-called Migration Compacts with Niger, Nigeria, Mali, Senegal and Ethiopia; however, diplomatic sources admit that in view of the number of immigrants crossing the Mediterranean, these agreements are not yielding the desired result except in the case of Niger. ${ }^{57}$

Hence, following the La Valletta Summit held in November of 2015, a new partnership framework has been established with third countries within the

55 European Commission, 'Green paper on an EU approach to managing economic migration' COM (2004) 811, which provides additional measures for integration, repatriation and cooperation with third countries, including the following (11-12): 'To provide updated information on the conditions of entry and residence in the EU, create training and recruitment centres in countries of origin in relation to the qualifications required in the EU, as well as language and cultural training, create databases on the skills/occupation/sector (competence portfolio) of potential migrants, facilitate the transfer of migrants' remittances and compensate third countries for the costs of teaching the people who migrate to the EU'.

56 European Commission, 'EU Strategy for Africa: Towards a Euro-African pact to accelerate Africa's development' COM (2005) 489 final. See 'La Comisión Europea aprueba un "Plan Marshall” para África' (12 October 2005) http://www.elmundo.es accessed 9 May 2019. In the words of Peral, this Plan would signify: 'Cancelling the debt of African countries, removing tariffs and agricultural subsidies to allow free access of African products to western markets, and quadrupling over the next ten years the 25,000 million dollars that western countries currently donate to Africa'. See Luis Peral, 'Vida, libertad y presión migratoria. Aproximación jurídica al problema de la devolución de personas en las fronteras de Ceuta y Melilla' (14 November 2005) Fundación para las Relaciones Internacionales y el Diálogo Exterior 7-9. See also European Commission, 'Priority actions for responding to the challenges of migration: First follow-up to Hampton Court' COM (2005) 621 final, which addresses those aspects of migration related to security and development (see in particular the initiatives referred to in paragraph III on 'Dialogue and cooperation with Africa and in particular Sub-Saharan countries of origin', 6-8), which served as the basis for the conclusions of the Presidency of the European Council in Brussels, 15 and 16 December 2005, appendix I to which was entitled 'Global Approach to Migration: Priority Actions Focusing on Africa and the Mediterranean'.

57 'España ha gastado 168 millones en frenar la llegada de cayucos a Canarias"' (20 June 2017) Elpais.com. 
context of the European Agenda on Migration. ${ }^{58}$ An EU Emergency Trust Fund for Africa was also created, as a policy instrument for local development aimed at fostering cooperation with third countries on migration issues. Within the framework of the above-mentioned trust fund, the Spanish Agency for International Development Cooperation (Spanish initials: AECID) worked actively in 2016 with the Ministry of the Interior, the Ministry of Employment and Social Security, and African countries to promote cooperation projects that address immigration. Of particular note in this regard, was the AECID's approval of a cooperation project with Morocco to support implementation of its new immigration strategy, with a focus on respect for human rights, developed by the General Secretariat of Immigration and Emigration. ${ }^{59}$

To conclude, we must emphasize that Spain must respect immigrants' human rights in expulsion/return procedures, in accordance with the Schengen Borders Code, the Return Directive and the EUCFR. Therefore, the special regime of Ceuta and Melilla or the reinforcement of border control to stop the migratory flows from Morocco to Spain cannot be alleged to the detriment of the procedural safeguards and the immigrants' human rights, recognized in Human Rights Treaties ratified by Spain.

But to curb migration flows, the reinforcement of border control must be accompanied by common policies in the European countries of destination and increased investment in the countries of origin and transit. Spain's bilateral cooperation with Morocco, Mauritania, Senegal and other African countries could be in this sense an interesting experience to be considered.

58 European Commission, 'La Comisión anuncia un Nuevo Marco de Asociación en Materia de Migración: una cooperación reforzada con terceros países para gestionar mejor la migración' (Press release, 7 June 2016); European Commission, 'Partnership Framework on Migration: Commission Reports on Results and Lessons Learnt One Year On' (Press release, 13 June 2017); European Commission, 'Fifth Progress Report on the Partnership Framework with Third Countries under the European Agenda on Migration', COM (2017) 471 final.

59 Consejo de Seguridad Nacional, 'Informe Anual de Seguridad Nacional', Part 8 'Ordenación de flujos migratorios' (2016) 117, 121. 